\title{
Shelf-stable pineapple slices preserved by combined methods
}

\author{
Humberto Vega:, Omar Martinez $z^{3}$ and \\ Gustavo V. Barbosa-Cánovas",A
}

\begin{abstract}
Pineapple slices were treated by two combined methods, packaged and stored at room temperature. The first preservation method consisted of blanching pineapple slices at $100^{\circ} \mathrm{C}$ for two minutes followed by a cooling period of 1.5 minutes at room temperature. The slices were then immersed in a $50 \%$ sucrose solution with $1,000 \mathrm{ppm}$ of potassium sorbate and 150 $\mathrm{ppm}$ of sodium bisulfite. The osmotic treatment was done at room temperature $\left(28.5 \pm 1.5^{\circ} \mathrm{C}\right)$ for 24 hours. The treated slices were removed from the osmotic solution, the excess syrup from the slices was removed, and the product was later packaged in sealed plastic bags. The final water activity values ranged between 0.95 and 0.97 for the packaged product. For the second preservation method, the pineapple slices were blanched in saturated steam for 12 minutes and stored at $12^{\circ} \mathrm{C}$ until processing by combined methods. Sucrose solutions (55 and $60^{\circ} \mathrm{Brix}$ ) with four different concentrations of potassium sorbate $(100,200,300$, or $500 \mathrm{ppm})$ were used as osmotic solutions. The water activity was 0.91 after the osmotic process and 0.88 after hot air drying. A shelf life of at least 30 days was observed for product prepared with both preservation techniques, and the sensory characteristics noted were similar to those in a commercially canned product (Del Monte canned slices). The inhibitory effect of potassium sorbate on yeast and mold growth was significant for concentrations above $300 \mathrm{ppm}$.
\end{abstract}

Key words: pineapple, shelf life, preservation.

\section{RESUMEN}

Rodajas de piña preservadas por métodos combinados

Se trataron rebanadas de piña con dos métodos combinados y se almacenaron a temperatura ambiente para evaluar su vida útil. El primer método de preservación consistió en escaldar la fruta a $100^{\circ} \mathrm{C}$ por dos minutos y luego enfriarla a temperatura ambiente $\left(28.5 \pm 1.5^{\circ} \mathrm{C}\right)$ por 1.5 minutos. Tras el enfriamiento se procedió a colocar las rodajas en almíbar al $50 \%$ de sacarosa con $1,000 \mathrm{ppm}$ de sorbato de potasio y $150 \mathrm{ppm}$ de bisulfito de sodio. El tratamiento osmótico se hizo a temperatura ambiente por 24 horas. Las rodajas se sacaron del almíbar y se empacaron en bolsas plásticas luego de escurrir la mayor parte del almibar. La actividad de agua del producto empacado fluctuó entre 0.95 y 0.97 . En el segundo método de preservación, las rebanadas de piña se escaldaron en vapor saturado por 12 minutos y se al-

'Manuscript submitted to Editorial Board 22 December 1993.

Department of Biological System Engineering, Washington State University, Pullman, WA 99164-6120.

3Department of Biology, University of Puerto Rico, Mayagüez, P.R. 00680.

'Author' to whom correspondence should be addressed. 
macenaron en refrigeración $\left(12^{\circ} \mathrm{C}\right)$ hasta su tratamiento por métodos combinados. Se usaron soluciones de sacarosa de 66 y $60^{\circ}$ Brix con cuatro niveles de sorbato de potasio $(100,200,300,500 \mathrm{ppm})$ para la deshidratación osmótica de las rebanadas. Una vez en equilibrio, se removieron las rebanadas de la solución de sacarosa y se secaron parcialmente con aire caliente por una hora. El valor de actividad de agua luego del tratamiento osmótico fue de 0.91 y bajó a 0.88 luego del secado parcial con aire caliente. Para ambos métodos de preservación se observó un período no menor a 30 dias durante el cual las características sensoriales del producto compararon favorablemente con las de productos comerciales de piña enlatada (Del Monte). El efecto inhibidor de sorbato de potasio sobre los hongos y las levaduras fue evidente a concentraciones mayores de $300 \mathrm{ppm}$.

\section{INTRODUCTION}

The combined methods technique combines the effect of low $\mathrm{pH}$, low water activity and antimicrobial agents to improve shelf stability while retaining more characteristics similar to those of fresh foods (Monsalve-González et al., 1993). Potassium sorbate, sodium bisulfite, sodium benzoate and other chemicals are used as preservatives in food products (Robach, 1980). The effect of sorbate and sulfite salts on yeast and mold activity and non-enzymatic browning is reported by Leistner et al. (1981), Alzamora et al. (1989), Vega and Silva (1991) and Vega et al. (1991). The preservation by combined methods of pineapple slices, guava, peach and papaya pulps is reported by Alzamora et al. (1989), Argaiz et al. (1993), García et al. (1993), and Flores del Valle (1993).

Foods preserved by combined methods typically have a moisture content of 65 to $85 \%$ and a water activity between 0.90 to 0.97 . The shelf life of fresh fruits is limited by factors such as ripening level, handling procedure and storage conditions. Therefore, processing alternatives may be considered to reduce post-harvest losses and to maintain fresh like quality food products.

The fundamental aspect of osmotic dehydration in fruits is the water transfer from the fruit to the osmotic solution and the incorporation of solutes into the fruit. Improvements in texture and flavor of fruit products are possible by lowering the acidity and increasing the sugar content as discussed by Chirife (1982). The difference in chemical potentials between the fruit and the solution is the driving force of the osmosis (Chirife, 1982). The water activity of the solution has to be less than the water activity of the fruit to promote the water transfer until an equilibrium condition is reached. The water activity of non-electrolyte solutions, such as sucrose, could be estimated by using the Norrish equation (Chirife el al., 1980):

$$
\mathrm{a}_{\mathrm{w}}=\mathrm{X}_{1} \exp \left(-\mathrm{k} \mathrm{X} \mathrm{X}_{2}^{2}\right)
$$


where $\mathrm{X}_{1}$ and $\mathrm{X}_{2}$ are the respective molar fraction for water and solute (sucrose for example) and $\mathbf{k}$, the Norrish constant.

In this study, the shelf stability of pineapple slices treated by two combined methods was evaluated and compared. To monitor the shelf stability of the packaged product while stored at room temperature for at least 30 days, we considered microbiological, chemical and sensory properties.

\section{MATERLALS AND METHODS}

Pineapples (Ananas comosus) were obtained from a local processor in Puerto Rico (Lotus, Land Authority of Puerto Rico, Barceloneta, P.R.) and processed by one of the following treatments:

\section{Treatment $\mathbf{A}$}

\section{Fruit preparation}

Treatment A consisted of blanching (saturated steam for two minutes) the slices ( $1.0 \mathrm{~cm}$ thick) of fresh peeled and cored pineapples followed by a cooling step at room temperature for 1.5 minutes. The slices were treated by combined methods immediately after the cooling period.

\section{Osmotic solution}

An osmotic solution was prepared by mixing commercial sucrose and water. The sucrose concentration was estimated with the Norrish equation for the preselected water activity values.

Two weight ratios (Sucrose:Pineapple) were considered for Treatment $\mathrm{A}(1.95 \mathrm{w} / \mathrm{w}$ and $2.59 \mathrm{w} / \mathrm{w})$, and the water activity values for the sucrose solutions, as estimated by Norrish's equation, were 0.95 and 0.97 . Sucrose solutions at room temperature were used to perform Treatment A. The potassium sorbate and sodium bisulfite used in the treatment $(1,000 \mathrm{ppm}$ and $150 \mathrm{ppm}$, respectively) were added and mixed well into the sucrose solution before any treatment. Sodium bisulfite was used to prevent nonenzymatic browning.

\section{Osmotic dehydration}

The pineapple slices were immersed in the osmotic solution $\left(50^{\circ}\right.$ Brix, $1,000 \mathrm{ppm}$ potassium sorbate and $150 \mathrm{ppm}$ sodium bisulfite) for 24 hours at room temperature. 
Packaging, storage and monitoring of physical, chemical and microbiological characteristics

'The pineapple slices were packaged in plastic bags and stored at room temperature. The viability of microorganisms was evaluated at the packaging step. Physical and chemical analyses (water activity, color, reduced and total sugars) were done on a weekly basis as recommended by the A.O.A.C. (1984).

\section{Treatment $B$}

\section{Fruit preparation}

Pineapples were peeled, cored, sliced, blanched (saturated steam for 12 minutes) and canned at the processor's facilities. The slices were $1.5 \mathrm{~cm}$ thick and $6 \mathrm{~cm}$ in diameter. The canned slices were stored at $12^{\circ} \mathrm{C}$ for a maximum of 14 days before the combined methods treatment.

\section{Osmotic solution}

A weight ratio (Sucrose:Pineapple) of $2.4 \mathrm{w} / \mathrm{w}$ was considered for Treatment B, and the water activity estimated by Norrish's equation was 0.91 . The temperature of the solution was set to $28.5 \pm 1.5^{\circ}$ $\mathrm{C}$ using a continuously agitated water bath (BLUE M Magni Whirl, N.Y. $)^{5}$. The potassium sorbate $(100,200,300$ or 500 ppm $)$ was added and mixed well into the sucrose solution before any treatment.

\section{Osmotic dehydration and hot air drying}

The pineapple slices were immersed in the osmotic solution (sucrose 55 or $60^{\circ}$ Brix with potassium sorbate $100,200,300$, or 500 $\mathrm{ppm}$ ) for four hours at $28.5 \pm 1.5^{\circ} \mathrm{C}$. Osmotic dehydrated slices from Treatment $B$ were partially dried in a convection oven (BLUE M. Power-O-Matic 60 , N.X.) at $70^{\circ} \mathrm{C}$ for one hour.

Packaging, storage and monitoring of physical, chemical and microbiological characteristics

The pineapple product was vacuum packaged in plastic pouches and stored at room temperature. The viability of microorganisms

\footnotetext{
"Trade names in this publication are used only to provide specific information. Mention of a trade name does not constitute a warranty of equipment or materials by the Agricultural Experiment Station of the University of Puerto Rico, nor is this mention a statement of preference over other equipment or materials.
} 
was evaluated 24 hours after the treatment and every 15 days during storage. The samples were homogenized in a Stomacher with a phosphate buffer ( $\mathrm{pH} 7.2$ ) as dilutent before each test. Potato Dextrose Agar with added chloramphenicol and tetracycline were used to isolate yeast and molds with an incubation period of five days at $27^{\circ} \mathrm{C}$. The yeast recovery was done with the Malt Yeast 50 media (Walker and Ayers, 1970) and a Millipore Yeast and Mold Testing Kit. The aerobic mesophilic organisms were isolated by using Standard Plate Count Agar with an incubation period of two days at $32^{\circ} \mathrm{C}$.

\section{Water activity}

The water activity of the solution and the fruit, for both Treatments $A$ and $B$, was measured as a function of time with an electrical hygrometer Aqua Lab CX-1 (Decagon Devices, Inc., Pullman, WA). Each reported value was calculated from an average of two measurements.

\section{Acceptability test}

An acceptability test for flavor, color and texture of treated pineapple slices was performed as a function of storage time. A hedonic scale of 0 (disliked extremely) to 5 (liked extremely) was used for each evaluation by a non-trained panel of seven judges. A similar test was performed on a commercially canned pineapple product (Del Monte canned slices). The evaluation of the Treatment A product was at 0 , $5,21,34,47$ and 55 days of storage, and of the Treatment B product at 10,20, and 45 days. The evaluation of Treatment $\mathrm{A}$ was slightly different from that of Treatment B because Treatment A was intended for longer shelf life and significant chemical and physical changes were expected. Therefore, we tested Treatment A more frequently and for a much longer period.

\section{RESULTS AND DISCUSSION}

\section{Treatment A}

The final water activity of the packaged product was 0.96 (product treated with $2.59 \mathrm{~kg}$ sucrose solution/ $\mathrm{kg}$ pineapple) and 0.97 (product treated with $1.95 \mathrm{~kg}$ sucrose solution $/ \mathrm{kg}$ pineapple). The mesophilic count of the packaged product was $15 \mathrm{CFU} / \mathrm{ml}$ and the yeast/mold count was $<10 \mathrm{CFU} / \mathrm{ml}$. A reduction in the ratio of sugars (reduced:totals) occurred while significant changes in color, flavor and aroma were reported by the panel of judges after 30 days of storage. The 
changes are attributed to non-enzymatic browning reactions. The formation of browning pigments is based upon the reaction of reducing sugars and amino groups, or Maillard reactions, in the product (White et al., 1970). Table 1a summarizes the chemical and physical results for the pineapple slices as a function of storage time.

\section{Treatment B}

The water activity was 0.91 after the osmotic treatment and 0.88 after the hot air drying at $70^{\circ} \mathrm{C}$ for one hour. The potassium sorbate restrained yeast/mold growth on those treatments with $300 \mathrm{ppm}$ or more. These results can be attributed in part to the inhibitory effect

TABLE 1.a.-Chemical and physical evaluation of pineapple slices treated by combined methods (Theatment A).

\begin{tabular}{|c|c|c|c|c|c|}
\hline \multicolumn{6}{|c|}{ Treatment A } \\
\hline \multicolumn{6}{|c|}{ Sucrose:Pineapple ratio of $2.59 \mathrm{w} / \mathrm{w}$. } \\
\hline Storage & Aw & & Color & & Sugars Ratio \\
\hline & & L & a & b & (Red./Tot.) \\
\hline 0 & 0.96 & 65.71 & -1.24 & 19.21 & - \\
\hline 5 & 0.95 & 67.24 & -1.51 & 19.19 & 0.82 \\
\hline 13 & - & 69.89 & -1.77 & 19.17 & - \\
\hline 21 & 0.96 & 67.22 & -1.63 & 20.38 & 0.58 \\
\hline 26 & 0.95 & 68.27 & -2.05 & 19.77 & - \\
\hline 34 & 0.96 & 67.01 & -0.90 & 17.39 & 0.71 \\
\hline 42 & 0.96 & 62.79 & -0.96 & 16.58 & - \\
\hline 47 & $一$ & 62.19 & -0.96 & 17.54 & 0.67 \\
\hline 55 & 0.95 & 61.80 & -0.04 & 18.73 & 0.42 \\
\hline 62 & 0.96 & 59.08 & -0.08 & 1.6 .49 & - \\
\hline \multicolumn{6}{|c|}{ Sucrose:Pineapple ratio of $1.95 \mathrm{w} / \mathrm{w}$} \\
\hline Storage & Aw & & Color & & Sugars Ratio \\
\hline (days) & & L & a & b & (Red./Tot.) \\
\hline 0 & 0.98 & 57.72 & -0.04 & 21.09 & - \\
\hline 5 & 0.97 & 61.44 & -1.26 & 18.21 & 0.82 \\
\hline 13 & 0.97 & 66.02 & -1.34 & 18.21 & - \\
\hline 21 & 0.97 & 55.77 & 0.90 & 21.64 & 0.68 \\
\hline 26 & 0.97 & 61.85 & -0.91 & 19.40 & - \\
\hline 34 & 0.96 & 62.58 & -1.04 & 21.42 & 0.81 \\
\hline 42 & 0.97 & 63.77 & 0.06 & 18.69 & - \\
\hline 47 & 0.96 & 53.38 & 0.31 & 16.68 & 0.63 \\
\hline 55 & - & 56.85 & 0.07 & 18.80 & 0.63 \\
\hline 62 & 0.97 & 62.00 & 0.61 & 17.80 & - \\
\hline
\end{tabular}


TABLE 16.--Physical evaluation of pineapple slices trealed by combined methods (Treatment B).

\begin{tabular}{|c|c|c|c|}
\hline \multicolumn{4}{|c|}{ Treatment $B$} \\
\hline \multicolumn{4}{|c|}{ Sucrose:Pineapple ratio of $2.4 \mathrm{w} / \mathrm{w}$} \\
\hline $\begin{array}{l}\text { Storage } \\
\text { (days) }\end{array}$ & $\begin{array}{l}\text { Suc./Pot. } \\
\text { Sorb. }\end{array}$ & $A w$ & $\begin{array}{l}\text { Color } \\
\text { (Visual Evaluation) }\end{array}$ \\
\hline 0 & $55 \% / 100 \mathrm{ppm}$ & 0.88 & Yellow \\
\hline 15 & & & Gas production observed \\
\hline 0 & $60 \% / 200 \mathrm{ppm}$ & 0.88 & Yellow \\
\hline 21 & & & Slight: Darkening \\
\hline 0 & $55 \% / 300 \mathrm{ppm}$ & 0.88 & Yellow \\
\hline 21 & & & Slight Darkening \\
\hline 0 & $60 \% / 500 \mathrm{ppm}$ & 0.88 & Yellow \\
\hline 21 & & & Slight Darkening \\
\hline
\end{tabular}

of the potassium sorbate after the heat treatment. The spoilage microorganism, appearing on the samples treated with less than 300 $\mathrm{ppm}$ potassium sorbate, was identified as the osmophilic yeast Saccharomyces (tentatively identified as Saccharomyces rouxii). The spoilage was characterized by the production of gas. Table 2 shows the microbiological counts for each experiment.

Color changes were noticed during storage. Slight darkening or browning was visible after three weeks of storage at room temperature. According to Karel (1975), Torreggiani et al. (1987) and Vega et

TABLE 2.-Aerobic mesophilic organisms and Yeast/Mold counts (CFU/g) on pineapple stices treated by combined methods (Treatment B).

\begin{tabular}{lccc}
\hline $\begin{array}{l}\text { Sucrose/Potassium } \\
\text { Sorbate }\end{array}$ & $\begin{array}{c}\text { Storage Time } \\
\text { (days) }\end{array}$ & $\begin{array}{c}\text { Yeast/Molds } \\
\text { (CFU/g) }\end{array}$ & $\begin{array}{c}\text { Aerobic Plate Count } \\
\text { (CFU/g) }\end{array}$ \\
\hline $55 \% / 100$ ppm & 1 & 20 & $<10$ \\
& 15 & Gas. Prod. & \\
$60 \% / 200 \mathrm{ppm}$ & 30 & 700 & $<10$ \\
& 1 & 36,000 & 32,000 \\
$55 \% 1300 \mathrm{ppm}$ & 15 & $<10$ & 1,200 \\
& 30 & $<10$ & $<10$ \\
$60 \% / 500 \mathrm{ppm}$ & 1 & 30 & $<10$ \\
& 15 & 20 & $<10$ \\
& 30 & $<10$ & 20 \\
& 1 & $<10$ & 90 \\
& 15 & $<10$ & 90 \\
\hline
\end{tabular}


TABLE 3.--Sensory evaluation of pineapple slices of Treatment $A$ and Treatment $B$ treated by combined methods, and commercially canned pineapples.

\begin{tabular}{|c|c|c|c|}
\hline \multirow[b]{2}{*}{ Treatment } & \multicolumn{2}{|c|}{ Treated Pineapple Slices } & \multirow{2}{*}{$\begin{array}{c}\text { Hedonic Value } \\
\text { Commercially } \\
\text { Canned Pineapple }\end{array}$} \\
\hline & Hedonic Value & Storage Time (days) & \\
\hline \multicolumn{4}{|l|}{ Treatment A } \\
\hline \multirow[t]{6}{*}{$0.95 \mathrm{Aw}$} & 4.0 & 0 & 4.0 \\
\hline & 3.6 & 5 & 4.0 \\
\hline & 3.6 & 21 & 4.0 \\
\hline & 3.7 & 34 & 4.0 \\
\hline & 2.5 & 47 & 4.0 \\
\hline & 2.0 & 55 & 4.0 \\
\hline \multirow[t]{6}{*}{$0.97 \mathrm{Aw}$} & 4.0 & 0 & 4,0 \\
\hline & 3.7 & 5 & 4.0 \\
\hline & 3.9 & 21 & 4.0 \\
\hline & 3.8 & 34 & 4.0 \\
\hline & 2.5 & 47 & 4.0 \\
\hline & 2.9 & 55 & 4.0 \\
\hline \multicolumn{4}{|l|}{ Treatment B } \\
\hline \multicolumn{4}{|c|}{$\begin{array}{l}\text { Sucrose/Potassium } \\
\text { Sorbate }\end{array}$} \\
\hline $55 \% / 300 \mathrm{ppm}$ & 3.7 & 10 & 3.6 \\
\hline $60 \% / 200 \mathrm{ppm}$ & 2.6 & 45 & 3.6 \\
\hline $60 \% / 500 \mathrm{ppm}$ & 2.0 & 20 & 3.6 \\
\hline
\end{tabular}

al. (1991), the presence of sucrose absorbed into the fruit tissue could accelerate the browning process. Treated pineapple slices had acceptable levels of flavor, aroma and palatability after 30 days of storage. Table 3 shows the evaluation results for the treated slices and for the commercially canned pineapple product.

3. Commercially canned pineapple product

In Puerto Rico canned pineapple slices, such as those used in this study, are a common dessert, with color, aroma and flavor similar to that of the fresh fruit. The commercial product selected had no sugar added by the manufacturer. An overall average of 3.9 in the hedonic scale was obtained when the canned product was tested by the sensory evaluation panel.

\section{CONCLUSION}

Shelf stable pineapple products at room temperature for at least 30 days were obtained when fresh fruits were treated by combined meth- 
ods. The sensorial properties of preserved fruits were similar to those found in a commercially available canned pineapple product (Del Monte). Blanching plays an important role in the initial reduction of microorganisms in the treated fruits (Vega et al., 1991), while the addition of potassium sorbate inhibits the growth of those organisms remaining in the product. The effectiveness of potassium sorbate was more evident in concentrations above $300 \mathrm{ppm}$. The above findings may indicate the potential marketability of these products as a minimally processed food.

\section{LITERATURE CITED}

1. Alzamora, S. M., L. N. Gerschenson, P. Cerruti and A. Rojas, 1989. Shelf-stable pineapple for long term non-J'efrigerated storage. Lebensm-Wiss. u-Technol. 22:233.

2. A.O.A.C., 1984. Official Methods of Analysis of the Association of Official Analytical Chemists. 14th Edition. Association of Official Analytical Chemists, Inc. Arlington, VA.

3. Argaiz, A., F. Vergara, J. Welti and A. López-Malo, 1993. Peach preserved by combined factors. In: Boletín Internacional de Divulgación No. 1. Programa Iberoamericano de Ciencia y Tecnología para el Desarrollo CYTED-D AHI, Mexico.

4. Chirife, J., 1982. Principios de la deshidratación osmótica de frutas. An. Asoc. Quim. Argent. 70:913-932.

5. Chirife, J., C. Ferro-Fontán and E. A. Benmergui, 1980. The prediction of water activity in aqueous solutions in connection with intermediate moisture food. IV. aw prediction in aqueous non-electrolyte solutions. J. Food Technol. 15:59.

6. Flores del Valle, W., 1993. Practical aspects of the obtainment of papaya pulp preserved by combined factors. In: Boletín Internacional de Divulgación No. 1 . Programa Iberoamericano de Ciencia y Tecnología para el Desarrollo CYTED-D AHI, Mexico.

7. García, A., I. Vicente, E. Sevillano, D. Castro, A. García, C. Casals, C. Fernández and M. Núñez, 1993. Preservation of guava pulp by combined methods. In: Boletín Internacional de Divulgación No. 1. Programa Iberoamericano de Ciencia y Tecnología para el Desarrollo CYTED-D AHI, Mexico.

8. Karel, M., 1975. Dehydration of foods. In: Principle of Food Science. Part II. Physical Principles of Food Preservation, M. Karel, O. K. Fennema, D. B. Lund (Eds.), Marcel Dekker, Inc., New York, USA.

9. Leistner, R., W. Rodel and K. Krispien, 1981. Microbiology of meat and meat products in high and intermediate moisture ranges. In: Water Activity: Influence on Food Quality, L. B. Rockland and G. F. Stewart (Eds.). Academic Press, New York, USA.

10. Monsalve-González, A, G. Barbosa-Cánovas and R. P. Cavalieri, 1993. Mass transfer and textural changes during processing of apples by combined methods. J. Food. Sci. 58(5):1118-1124.

11. Robach, M. C., 1980. Use of preservatives to control microorganisms in food. Food Tech. 10:81-84.

12. Torreggiani, D., E. Forni and A. Rizzolo, 1987. Osmotic dehydration of fruit. Part 2 : Influence of the osmosis time on the stability of processed cherries. J. Food Proc. Preserv. 12:27.

13. Vega, H., I. Beauchamp, N. Díaz and J. Cruz, 1991. Efecto de la escaldadura en la vida útil y aspectos químicos de los productos de piña de humedad intermedia. $J$. Agric, Univ. P.R. 75(1):25-36. 
14. Vega, H. and L. Silva, 1991. Research Note: Efectividad de preservativos durante el almacenamiento en productos de pina de humedad intermedia. J. Agric. Univ. P.R. $75(4): 411-415$.

15. Walker, H. W. and J. C. Ayres, 1970. Yeast as spollage organisms, In: The Yeasts, A. H. Rose and J. S. Harrison (Eds.). Vol. 3, Acadernic Press, Inc., New York, USA.

16. White, A., P. Handler and E. L. Smith, 1968. The Carbohydrates - I. In: Principles of Biachemistry. 4th Edition. McGraw-Hill Book Comp. New York, NY. 